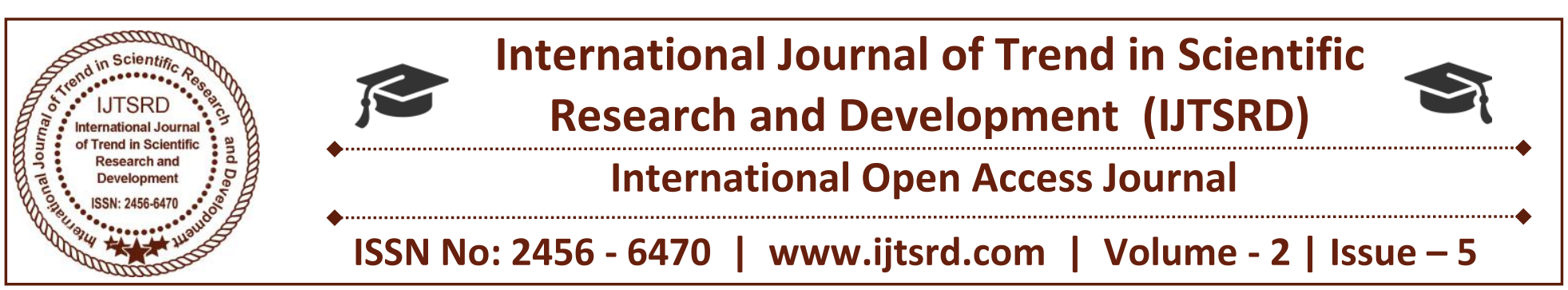

\title{
Determinants of Bank's Non-Performing Loans: A Case Study of Pakistan
}

\author{
Bilal Mahmood \\ Researher/ Student, Institute of Business Administration, University of the Punjab, Lahore, Punjab, Pakistan
}

\begin{abstract}
The purpose of this study is to find the determinants of bank's non-performing Loan in the context of Pakistan. This secondary study used panel data of 39 banked across 6 years (2006-2011) in Pakistan. The current study used total 11 variables in which three macroeconomics and eight bank specific variables. Data is collected from State bank of Pakistan (SBP) annual reports, Pakistan economic surveys. The pooled OLS technique and used to estimate the effect of bank specific and macroeconomic variables to explore the determinants of NPL. Results reveal that Unemployment (UN) and real lending rate(RLR) is positively associated with Non-Performing Loans and Gross Domestic product(GDP) is negatively associated with NPL. The study concluded that NPLs for private domestic banks is more than public banks. In the last quarter of 2011, the NPL was at Peak due to heavy flood and rain. The NAB (National accountability bureau) must established mobile courts for early settlement of Problem loans cases and state bank of Pakistan must update the CIB (Credit information bureau) report on daily basis. This study more focused on macroeconomic variable instead of bank specific variables.
\end{abstract}

Keywords: Unemployment, Determinants, NonPerforming Loans, Pakistan

\section{INTRODUCTION}

Pakistan being one of the greatest countries of South Asia has an amazingly fast rising and extending economy. Pakistan economy has made at a yearly ordinary GDP improvement rate of around 6 percent from 2000 to 2008 and 7 percent in some year back. (SBP; Publications). Developing economy, provides growth opportunities to banks there are great future planned for outside banks in Pakistan that is the reason a vast numeral of remote segment banks are attracted towards banking industry of Pakistan banking Industry which cause increase in competition in banking industry, and results in improvement of service quality and innovation of banking products is giving and touching new skylines of value administrations and development.

Pakistan's saving money industry made out of the National Bank of Pakistan (SBP), business region banks, Investment division banks, called as corporate banks, Micro Finance portion Banks, and headway banks. The business banks can be accumulated as Nationalized, Privatized, select and remote asserted banks. As on Dec. 2010, It fuses four open had banks, twenty Privatized Banks, six Foreign guaranteed Banks, five Islamic part Banks, four particular Banks and seven Micro Finance division Banks (State Bank of Pakistan). The nationalized business banks (NCBs) are encountering expansive modifying Programmed. Private Banks are hardening their circumstance by growing their paid-up-capital and creating branch mastermind.

A straightforward meaning of non-performing advance is: An advance that isn't acquiring wage and: (1) full installment of primary and intrigue is never again expected, (2) standard or intrigue is 90 days or more delinquent, or (3) the advancement date has passed and portion in full has not been made (Yixin,2006). Prior in Pakistan factors like political weight, administrative shortcoming and inward factors inside the bank's organization as the purposes behind the deficiency of the dealing with a record part But in few decades the non performing loans got high importance in all over the world. It negatively effects banks profitability and ultimately leads to failure of 
banking system. Banking emergencies are a genuine concern and can be to a great degree expensive-not similarly to the extent the quick cost to governments and subjects, yet what's more to the extent declining being developed (Dermirgue\&Kunt1989)(Barr \& Siems1994).

In current scenario, Non-performing loans (NPLs) is increasing very vastly. The non-performing credits influence banks' loaning conduct in various nations and districts. Non-performing advances can prompt effectiveness issue for keeping money segment. There is a negative connection between the non-performing credits and execution effectiveness (Kwan and Eisenbeis (1994), Hughes and Moon (1995), Resti (1995). At global level economists, rating offices, and associations, for example, the World Bank and the Asian Development Bank (ADP) have started to assess the impacts of NPLs on GDP development. There are many factors like political influence, interest rate, poor management e.t.c. reasons responsible for this increase in nonperforming loans. The most of the people take loan on political bases and cannot pay back, if the bank demands then they threat the bank's people. Likewise if interest rate falls it reduces borrowing cost of borrower but if the interest rate increased, it may lead to unaffordability and ultimately increasing the NPL portfolio, which caused reduction in banks profitability.

The changed in genuine pay as demonstrated by development in genuine GDP delivered huge negative impact on NPLs. The banks which are forceful in loaning and charge generally higher financing costs bring about more noteworthy NPLs. In Pakistan NPLs remained at Rs 613 billion for all saving money segment restrictive of back advancement organizations, according to information gave by State bank of Pakistan. In term of percentage it reached up 6.4 percent of gross loan, in this 15.1 percent is contributed by publically held banks and 14.7 percent is contributed by particular banks (SBP, September 2011).Likewise Tunisia and Egypt show the most elevated amounts of NPL, with $21 \%$ and $24 \%$ of gross credits over the period 2002-2006 individually. NPLs are additionally dangerous in United Arab Emirates (12\% of gross advances) notwithstanding of late budgetary framework changes. At the inverse, different nations, for example, Kuwait and Saudi Arabia don't appear to experience the ill effects of issue credits $4 \%$ and $5 \%$ individually ((YixinHou, 2012)
Another main reason of increase in NPLs in Pakistan is excessive government borrowing and energy crisis. During the current financial related year from July 1 to February government acquired Rs. 190 billion from the SBP, while indicate getting of government came to up to gigantic measure of Rs 700 billion. The indefatigable imperativeness inadequacies caused gathering and material part need to obtain more than their commonplace working capital need. The essential instance of gas lack on gathering part is the world's greatest single-get ready urea delivering plant which isn't working in light of the unusual supply of gas. The total cost of the wander is over $\$ 1$ billion which is financed by the banks essentially. What's more the further decreasing of 100-200 start centers in the present market financing expenses would not obligated to energize the advancement in private region crediting, in light of the infrastructural issues and imperativeness inadequacy issues. (Ahmed and Bashir, 2013)

There are two types of factors influencing loan portfolio of commercial banks in India. There is significantly positive connection between nonperforming credits and the genuine compelling conversion standard. It came about into crumbling of universal intensity of the nearby economy (as reflected by a thankfulness in the genuine successful conversion standard) may bring about larger amounts of non-performing advances. The budgetary factors, for example, development, cost and terms of credit(TOC), banks size, and credit introduction affect fundamentally on the NPLs of business banks in India(Rajan and Dhal (2003). There is immediate relationship exist between the advance misfortune rate and interior factor, for example, high financing costs, unreasonable, and unstable assets (Sinkey \& Greenwalt, 1991). Also, another specialist reasoned that there is a solid relationship exists between credit development and debilitated resources. The speedy credit improvement, which was connected with cut down credit measures, added to higher propel incidents in particular states in the US.(Keeton (1999))

The financing cost not just fills in as the fundamental determinant by banks in credit endorsement. The wonders that banks are hesitant to confer new advances is portrayed as the "'credit crunch" issue The Credit nature of banks is likewise decidedly influenced by the pertinence of the data distributed by open and private departments; however there are a 
few factors that lessened the NPL like investment originating from created Countries, high credit development, and advance misfortune arrangements, better control of defilement, a sound administrative quality, a superior authorization of run of law, and a free voice and responsibility assume a vital part in decreasing nonperforming advances (YixinHou, 2006)

The connection between the loan fee change and the genuine financial action happens by speculation and buyer solid consumption. The money emergency in 1997, the loan fee was raised. It was unequivocally accepted by IMF that the climb would help balance out the outside cash showcase and in the end prompt keeping money change by expelling low-benefit ventures. The persevering fall in monetary development rate and the gigantic financial retreat created question on the genuine advantages of the strategy and the adequacy of the customary perspective of the banks as transmission medium. The State Bank of Pakistan (SBP) is dealing with the NPL issue in a comprehensive path through (an) adjustment in degree and uncovering of NPLs (b) a proactive treatment of the present heap of NPLs (c) stemming stream of new NPLs and (d) improving the technique and authoritative condition. The State Bank of Pakistan conveys its best push to upgrade danger organization interminably to diminish the NonPerforming Loans, one of the main problems of banks as it hampering the profitability. In the Pakistani sparing cash crisis of 1996-1998, (Hardy and di Patti (2001) exhibit that credit boss contributed clearly to the bank dissatisfactions by diverting noteworthy measures of advantages for their own pick up. The Foreign proprietorship is known to positively affect banks' soundness. Banks gainfulness likewise influenced by chance taking conduct of banks, Banks with high benefit are less keen on income creation and in this way less obliged to take part in unsafe credit contributions. Godlewski (2004) utilized ROA as an intermediary to investigate execution of Financial establishments, demonstrated that banks gainfulness adversely impacts the level of nonperforming advances proportion.

The business obsession in like manner impacts the credit threat of the banks. There is an immense positive connection between dealing with a record industry obsession and non-performing propels and in that union of banks more energetic firms (cut down
Quality borrower) are financed by banks more as conversely with centered markets (Breuer (2006)

Fofack (2005) broke down the huge scale money related markers of Sub-Saharan African countries. The money related improvement, bona fide change scale gratefulness, the authentic financing cost, net premium edges, and between bank credits are critical determinants of NPLs in these countries. The greater number of banks controlled by government provoke bringing down of NPLs. The bank evaluate is unfavorably related to NPLs while development may not be a determinant (Hu et al (2006)

Keeping in mind the end goal to accomplish the target of the investigation about deciding NPLs, utilized board information of 39 business banks of Pakistan for the time of $2005-2011$.

NPLs are not an issue of Pakistan; it is the issue of every growing economy. Excessive increase in NPL attracts world researcher's attention towards NPL. As a result of NPL most nations and additionally banks progress toward becoming default. Thus, the purpose of this paper is to inspect the determinants of NPL

The examination have been convinced to research the determinants of non-performing credits in Pakistan, as in most recent two decades the NPLs level achieved 6.1 percent of gross advances, a definitive impact of extensive NPLs on managing an account framework is banks disappointment. In past this zone got less consideration of scientists in Pakistan .The more elevated amount of non-performing advances lessens banks' goal to expand loaning as contrast and banks having low NPLs level. It is exceptionally important to annihilate the non-performing advances and keep away from economy from stagnation and enhance monetary status. In the event that the level of NPLs increments $\square$ the weaker corporate segment makes banks more hesitant to give extra credits $\square$ inadequate capital, the generation division is additionally debilitated, bringing about abatements in total request $\square$ once more, far and away more terrible borrowers' condition makes more NPLs. So the non-performing advances leads to hindering the economic growth and reduced the economic inefficiency. This issue is needed to be addressed, to improve economic efficiency and make Pakistan strong. 
2. Previous literature and hypothesis development A brief review of a few earlier studies conducted on determinants of banks Non-performing is discussed in this chapter. Literature review of past investigations gives a solid comprehension and gives a superior thought in regards to NPLs and its elements. It likewise featured strategy, discoveries, proposals and constraints of past examinations. which are reported on a similar region however for various nations and condition.

Gambera (2000) formed the groups of banks on the basis of assets size, geographical location and considered the average behavior of groups with in business cycle. Separation the issue credits into two classes i.e. wrongdoings and non-performing advances and utilized quarterly information of 1987Q1-1999Q4 of USA banks and connected straightforward OLS strategy to research financial improvement effect on the advance quality. The advance quality was relapsed against joblessness land credits, area wage, number of liquidations, agrarian advances and auto deals, business and modern advances. This paper assumed that modification in macroeconomics factors have impact using a loan quality and proposition changes in macroeconomics variables and business cycles can be used to guess changes ahead of time quality.

Sales \&Saurina (2002) investigated the connection amongst macroeconomic and singular banks and NPLs and utilized Spanish banks load up data over the season of 1985-1997 and used powerful model to inquire about the determinants of NPLs. This paper characterized issue advance as dubious in addition to Non-performing and gathered information from statically yearbook of bank distributed by AEB. They found that NPL is affected by bank estimate, genuine GDP development rate, advertise control, quick credit extension, capital proportion, net premium edge, wastefulness, capital proportion, family indebtness, hazard premium, issue advance without guarantee and obligation to value proportion. They recommended that GDP advancement, forgiving credit terms and high honest to goodness advance charges are critical determinants of NPLs

Chandra (2003) studied Non-performing advances (NPL) and conditions for credit out in the open business area banks of India and utilized the information of open banks and connected relapse investigation. To make it all the more clear connected distinctive proportions like working expense to add up to resources, NPL to add up to resources, NPL to add up to risk, GNPA to Assets, NPA to Gross advances. He discovered bank measure, insurance esteem, financing cost, condition (GDP), development, likelihood of default (PD) have huge impact on the terms of credit and NPLs. The examination inferred that the bank estimate estimated regarding resources has negative effect on NPAs and bank measure as far as capital has positive noteworthy impact on NPAs. Likewise found that (TOC) Variable has noteworthy impact on the bank's NPL, inside seeing bank evaluate and macroeconomic paralyzes. What's more the components like horizon of advancement of credit, better credit culture, and perfect Macroeconomic and business conditions incite bringing down of NPAs.

Masood, Bellalah, Mansour, and Teulon (2004) examined the role that credit managers have on lending nonperforming bank loans (NPLs) and adopted a comparative approach to investigate the leading question in both Pakistan and turkey respectively. The researcher collected data through face-to -face interviews with top credit managers of Pakistan and Turkey. In Pakistan the credit decision of manger is influenced by some external factors such as personal interest and political influence. Likewise in turkey Regulations, Practice and quality no longer consistent driver for explaining the NPL. They connected the requested probit display models on essential information gathered through reactions on surveys from the senior administration of the best business banks of Pakistan and turkey. They presumed that in turkey government impedance in loaning choices prompts increment in NPL and furthermore the poor appraisal of credit hazard and a feeble capital base impact nonperforming bank advances. They frequently settled using a credit card choices by utilizing individual judgment instead of utilizing particular loaning systems. In Pakistan the three factors that fundamentally impact NPL's are correspondence offices gave to the credit chiefs (CF), the credit director's times of administration in the bank (YOS) and years of experience as a credit administrator (YOE). Correspondence offices gave to the credit administrators created negative effect on non-performing advances while credit chiefs' times of administration and years of experience are decidedly related with non-performing bank advances. So thinks about finding upheld the Mosood (2004), sees expressed that credit directors' basic leadership amid the Pakistani managing an account emergency was 
enormously affected by outside components, for example, individual intrigue and political debasement.

Yonhee (2006), investigate the determinants of banking sector non performing loans and capital adequacy measured by BIS ratios. Also determined the effects on market structure under different regulatory regimes. i.e. Stringent rate of return, while unwinding value top direction, diminishes the balance of banks. This examination utilizes the one of a kind informational index of whole saving money in Korea between1976 - 2003 and secured the both circumstance when saving money emergency. Examination comes about demonstrates that after the usage of safeguard modified the level of NPLs lessens over the time in post 1997. The positive relationship exists between showcase focus (size) and NPL proportions which can be inspected by antagonistic market impacts broke down by growing dangerous credits. Capital sufficiency is decidedly affiliated with advertise fixation. Close by the merger between the residential business banks, M\& A movement by remote banks has recently begun to wind up a politically and socially satisfactory in saving bothered Korean business banks. The effect of various kind of union, cross-money related part mergers liable to be a fascinating zone for future examination.

Khalid (2006) inspected the impacts of privtization and advancement on saving money segment of pakistan and connected CAMEL outline work of proportion examination i.e Capital sufficiency, Asset quality, Management soundness, income and productivity, Liquidity, Sensitivity to advertise hazard. He found that elements like assembling residential funds, gainful venture, great business openings, diminishing data, exchange, and checking costs, expansion of hazard, aggregation of physical and human capital, and quicker innovative advance impacts emphatically to the effectiveness of banks. Additionally found that whole managing an account division demonstrates change however private has been less tasteful in light of the fact that a large portion of the banks claimed by representatives. The generous execution and effectiveness increases can be accomplished by exchanging responsibility for/FI's from people in general division to private hands.

Jakubík (2007) explored the connection between macroeconomic improvement and credit portfolio quality and utilized the quarterly information for Czech economy keeping money division at that point connected relapse examination to research the effect of illustrative factors that is genuine GDP, genuine powerful, advances to GDP proportion, trade rates, joblessness, genuine financing cost and expansion on subordinate Variable Non-performing advances (NPLs) by utilizing Czech Republic managing an account segment information. It reasoned that exceptionally solid connection between bank portfolio quality and the macroeconomic condition. The corporate default rate is out and out directed by the improvement in credit to GDP extent and authentic convincing transformation scale appreciation while if there ought to emerge an event of families, advancement in advance cost and joblessness prompts augment in NPLs.

Babihuga (2007) researched the linkages between monetary strength pointers (FSIs) and macroeconomic factors and utilized the information from Asian, European and Sub-Saharan African nations comprising of 96 nations of period 1998-2005. At that point utilized relapse examination to explore the connection between factors like swelling, the genuine successful conversion standard, and genuine loan costs, net intrigue edges, terms of exchange, productivity and resource quality, joblessness and NPL. They relapsed NPLs against dealing with a record zone headings and supervision, business cycle some portion of GDP. The ponder contemplated that budgetary soundness pointer (FSIs) change immovably with the business cycle and the swelling rate and business cycle, extension, Interest rates and the certifiable practical swapping scale, authentic GDP has a strong negative association with the NPLs and capital sufficiency. NPLs against managing an account area directions and supervision, business cycle part of GDP. The contemplate reasoned that budgetary soundness pointer (FSIs) change firmly with the business cycle and the swelling rate and business cycle, expansion, Interest rates and the genuine viable swapping scale, genuine GDP has a solid negative connection with the NPLs and capital ampleness.

Adhikary (2008) examined the Non-Performing loans after the adoption of prudential regulation wheather it effets the magnitude of NPLs on managing an account segment of bangladesh and utilized information of four nationalized business banks, 5 governementpossessed advancement budgetary instituations, 30 private business banks and 10 outside business banks for time of 1990 to 2005 and connected statiscally 
anlysis to check the arrangement of NPL. The study concluded that decline in the credit quality, disastisfactory performance of the courts, poor enforecement of laws, out of court settlement produce positive effects on NPL.The borrower true cooperation,sincerity and acountability of invloved parties only way to eradicate this problem.

Zeman and Jurèa (2008) examined the effect of stoppage in monetary exercises on saving money part of Slovakia and utilized both vector connection show and multivariate board relapse investigation on Slovakia managing an account segment information; the board relapse primarily comprises of three proportion i.e. money related use, liquidity proportion and genuine GDP development rate. They utilized NPLs as autonomous variable and genuine GDP, exchanges, the yield gap, oil costs, industry age, Money supply, swelling, change standard and apparent credit expense as illustrative elements. It assumed that bona fide GDP, the apparent advance cost and swapping scale are the most basic influencing factors on the NPL s. Monetary course of action is basic to help the sparing cash section.

Ahmed, Farooq\&Jalil (2009) narrated that Pakistan's administrative experts did changes with the help of Japanese government and World Bank in the dealing with a record part adjustment propel program (BSAL) in cash related territory in 1990s. The pivotal target of these progressions was to develop the Total Factor Productivity (TFP) of whole cash related system, paying little mind to whether budgetary changes impacted the total factor gainfulness (TFP) of dealing with a record division of Pakistan. Consequently they stepped through exam of 20 private banks of Pakistan and figure their capability through data envelopment analysis(DEA) and Malmquist record of total factor gainfulness from 1990 - 2005.Along with cash related changes there are moreover extraordinary components like higher center cost, mammoth utilization, wander on establishment, overstaffing and loss of arrangement of branches that effects. They watched that the total factor benefit (TFP) would increase by fortifying the organization and overhaul obligation through disengaged ownership structure. In like manner found that money related section changes are productive in upgrading the profitability of the neighborhood business banks part as intermediations.

Marcucci and Quagliariello (2009) investigated the cyclical behavior of default rates of Italian banks more than two decades and found that default rates reduce in fantastic macroeconomic conditions and enlargement amidst downturns. They used vector auto backslide (VAR) showing methodology to choose the effect of macroeconomic paralyzes on sparing cash section and how corporate and family fragments react to these macroeconomic shocks. They used elements like default rate for the family part, the yield opening, the extent of families' commitment to apparent GDP, the yearly development rate, and the apparent financing cost as enlightening components and NPLs as dependent variables. The examination assumed that default rates took after a rehashing case and banks may diminish advancing which therefore unfavorably impacts the yield levels. They moreover found that there is a feedback from the keeping cash division to the substantial scale economy by methods for bank capital channel.

Abd-el-Kader (2009) investigated the effect of compelling supervision on Non-performing credits and gathered a board information (as blend of both cross sectional and time arrangement) from IMF Global Financial Stability Reports of 59 nations over the period 2002-2006. Then connected total Financial Soundness Indicators (FSI), diverse proportions like Return on resources proportion (ROA), level of monetary advancement, capital ampleness proportion (CAR), Return on resources proportion (ROA) e.t.c. what's more, experimentally dissected the crossnations determinants of nonperforming advances and the impact of administrative factors using a credit card chance. It found that a considerable measure factors impacted on NPLs like level of remote bank, level of state possessed banks, the slacked genuine GDP development, Capital administrative record, supervisory power, Bank benefit, straightforwardness, popular government, defilement. The compelling method for lessening credit chance presentation through improving the lawful framework, fortifying foundations and expanding straightforwardness and majority rules system. Likewise found that higher capital ampleness proportion and reasonable Provisioning strategy appears to lessen the level of issue credits. There is solid proof on relationship amongst NPLs and bank particular factors like capital Adequacy proportions, arrangements, bank possession and the level of money related improvement. The financial conditions don't altogether affect bank credit results. 
Prasad(2010) examined the reasons for expanding NPLs in managing an account arrangement of GCC(Gulf states) and their macroeconomics effects. The ponder took 80 banks as test and investigate board informational collection and utilized VAR display and settled the impacts and connected distinctive proportions like costs/resource proportion, the cost/pay proportion, Return on Equity. There are distinctive calculate prompts increment NPL like financing costs, hazard avoidance, advance development, insurance, net-premium edge, obligation to value, advertise control, Unemployment, swapping scale, Housing costs ,Non-oil GDP,Inflation ,Total Loans, Credit development. The investigation inferred that noteworthy reverse relationship exhibit between genuine (non-oil) GDP and NPLs. Additionally found that NPLs increments as bringing down of loan fees and hazard avoidance.

Louzis, vouldis and Metaxas (2010) utilized board information strategy to inspect the determinants of nonperforming credits (NPLs) in the Greek managing an account division, independently for each sort of loan(consumer, business and home loan loans)and utilized both macroeconomic and bank-particular factors impact on advance quality. The examination inferred that NPL in Greek saving money part is affected by full scale essentials like genuine GDP development rate, joblessness, loan cost and administration quality and furthermore found that home loans being less responsive towards changes in the macroeconomic conditions and controllers should put more conspicuous highlight on risk organization structures and procedures took after by banks remembering the true objective to get some distance from future fiscal instability.

Karim, Chan and Hassan (2010) investigate the link between non-performing advances (NPLs) and proficiency of the banks and utilized real information of both Malaysian and Singaporean banks from 1995 to 2000.To estimated the productivity of banks they quantified the cost effectiveness through the stochastic cost boondocks technique. The results demonstrated that there is no basic qualification in cost efficiency between banks in Singapore and Malaysia regardless of the way that banks in Singapore show a higher ordinary cost viability score. The relapse examination checked that higher the measure of NPLs decreases the cost proficiency; in like manner bring down cost effectiveness increments non-performing advances. Poor administration in banks is another vital factor which cause increment of NPLs. The outcomes additionally predictable with the examinations by Altunbas (2000), Fan and Shaffer (2004), and Girardone (2004) that discovered nonperforming credits prompt wastefulness in the keeping money division. Moreover, the outcomes additionally upheld the hypothesis of terrible organization which suggested that poor organization in the dealing with a record foundations achieves horrendous Quality credits, and thusly extends the level of nonperforming.

Festiet al (2011) examined the macroeconomics and bank particular factors as wellspring of efficient hazard and explore their effect on defenselessness of managing an account segment towards NPLs (Nonperforming credits) at a macroeconomic Level of five new European Union States. The factors included store to credit proportion, remote direct speculation (FDI), Loan to resources proportion, trades, net outside advantages for net resources proportion, advancement of the keeping money part, budgetary extending, showcase focus, and gross settled funding to GDP and pay of workers and Basel center guideline as logical factors and Non-performing advance as needy variable and connected both board relapse technique to settled impact and arbitrary impact models for the investigation. The examination reasoned that increments in financial movement prompts decrease in NPLs, in addition increment in advance to resources proportion support up the NPLs in light of the fact that advances on simple terms and conditions given by banks. The gross settled capital prompt increment in GDP and eventually prompt decrease in NPLs and development in fares and industry generation at last increment NPLs proportion.

Nkusu (2011) investigatethe connection between Nonperforming credits (NPL) and macroeconomic factors chiefly GDP development and joblessness and utilized board vector autoregressive (PVAR) display on yearly information from 1998 to 2009 for an example of 26 propelled nations. The factors included NPLs as free and GDP development, joblessness, change in the house value file, change in the value record, expansion, ostensible powerful conversion standard, approach rate of intrigue, and credit to the private part as illustrative factors. The examination presumed that yield has non-straight effect on NPLs and GDP development and joblessness causes a descending turn on keeping money framework, the 
crumbling in monetary movement strengthen each other.

Farhan (2012) examined the reasons of expanding Non-performing credit in Pakistan managing an account part and utilized essential information gathered from senior brokers of best 10 banks through questionaure.Then connected expressive investigation and relapse to decide correct connection between factors. The investigation found that financing cost, Energy emergency, joblessness, Inflation, conversion scale have positive association with Non-performing advances and huge negative association with GDP development.

Haneef (2012) investigated the connection between the hazard administration and Non performing advances in keeping money part of Pakistan and utilized a mix of both essential and optional research and computed distinctive kind of hazard like Credit chance, financing cost chance, liquidity chance, administrative hazard, cash hazard, and HR chance and connected with NPLs. The examination gathered information from evaluated yearly reports, financial matters distributions, other statutory proclamation, national bank Publication, squeeze cutting, meetings and surveys of five best banks, just to decide the impacts of market hazard, credit chance, liquidity chance and operational hazard on NPL and gainfulness of banks. The examination inferred that NPL is expanding because of absence of hazard administration which debilitates the gainfulness of banks and Pakistani banks does not have a different hazard administration division nor chance council which maintains a strategic distance from chance.

Siddiqui, Shahzad and Shah (2012) examined that intrigue unpredictability prompts flighty inflows and outpourings from borrower who may spare more if there should arise an occurrence of lower financing costs on one side and then again side may reach to the levels of exorbitance prompts defaults and expanding NPls arrangement of the loan specialists that created noteworthy negative effect on the economy. The investigation is centered around Pakistan where nonperforming credits are expanding at a wild rate and gathered information for time of 1996Q4 to 2011Q3 through GARCH. The Regression investigation demonstrated that NPL not just affected by unpredictability of loaning rates charged yet additionally other macroeconomic components that prompt increment in NPLs. This gave essential ramifications to strategy producers and experts, to investigate the impacts of loan fees developments on the total monetary structure comprehensive of the cost of obtaining. Alternate factors that impacts the NPLs like political unsteadiness, Pakistan's continuous cutting edge part in world's war against fear mongering, administrative edge work, mergers and acquisitions, loaning methodology of banks, resource quality and collateralization.

The current writing on NPLs proposes both full scale monetary and bank particular factors influence the non-performing credits. In view of existing writing and accessibility of every factor information current investigation incorporated the mix of both bank particular and large scale monetary factors which are as take after Gross residential item, Unemployment, wastefulness, genuine loaning rate, showcase control, estimate, dissolvability proportion, rate of return, return on value, Loans to store proportion, Credit development and furthermore created nine theory relating relationship amongst NPLs and chose factors. The speculations are given beneath.

On the bases of past examinations, the present investigation /Cincluded seven theory relating relationship amongst NPLs and twelve included factors (both full scale and bank particular). These theories are given beneath:

H1: The growth in GDP results in the decline of NPLs. The negative association present between nonperforming loans and GDP growth.

\section{Unemployment effect Hypothesis}

$\mathrm{H} 2$ : The increase in unemployment rate results in the growth of NPLs. The Positive association present between nonperforming loans and unemployment rate.

Real lending rate effect hypothesis

H3: The increase in interest rate results in the growth of NPLs.The Positive association present between nonperforming loans and RLR

\section{Size effect hypothesis}

H4: The increase in the size of the bank results decline in NPL. The negative association present between nonperforming loans and size. 
Bad management hypothesis

H5: The worse performance is positively associated with increases in future nonperforming loans. The performance is used as a proxy for the quality of management

\section{Moral hazard hypothesis}

H6: The decrease in capitalization of banks prompts an expansion in nonperforming credits. Because of good danger impetus with respect to banks' chiefs who increment the hazard of their credit portfolio when their banks are meagerly promoted.

Gross advance to deposits hypothesis

H7: when greater amount of deposit allocating for landings, it leads to increase in NPLs. The positive association exists between the GAD and NPLs.

\section{Research design}

This section covers the examination plan, technique used to explore inquire about inquiry of this investigation. Information examination systems, meaning of factors, information sources and testing of firms, Econometrics' models alongside scientific particular are nitty gritty in this section. The motivation behind this examination is to contribute towards an imperative zone of keeping money framework that is tricky advances in Pakistan.The survival of banks depends upon the effective management of non-performing loans which ultimately affects the profitability and liquidity of banks. It means efficient management of credit is inevitable.

\subsection{Data Source and Sample:}

This is a secondary study which is conducted to examine the determinants of non-performing loans which ultimately affects the profitability and liquidity. It comprises panel data of 39 banked across 6 years (2006-2011). The current study used total 11 variables in which three macroeconomics and eight bank specific variables, these are selected on the bases of literature review and availability of each variable data. Data is collected from State bank of Pakistan (SBP) annual reports, Pakistan economic surveys. The pooled OLS technique is used to estimate the effect of bank specific and macroeconomic variables to explore the determinants of NPL.

\subsection{Descriptive Analysis:}

Descriptive examination of chose factors was performed to depict their general conduct, for example, mean esteem, standard deviation, least and greatest esteem. For engaging examination Views programming was utilized

\section{Dependent Variables:}

Firms' non-performing loan (NPLGA) is used as dependent variables in this study.

\section{Independent Variables:}

The total independent variables are 11 in which three macroeconomics and eight bank specific variables, these are selected on the bases of literature review and availability of each variable data. These macro variables included, GDP, Unemployment, interest rate and bank specific variables included Return on Assets, Return on Equity, Solvency ratio, Gross advance to deposits ratio, Inefficiency, Credit growth, Market power, Size.

\section{Justification of Variable Selected:}

The decision of GDP, joblessness and financing cost as the essential determinants of NPLs may likewise be advocated from the hypothetical writing of life-cycle utilization models. The utilization of joblessness and genuine loaning rate alongside GDP, since it gives extra data with respect to the effect of macroeconomic conditions on family unit and firms. On the off chance that there is increment in the joblessness rate should impact contrarily the income surges of family units and increment the obligation trouble. The borrowers with low livelihoods have higher rates of default. It implies when there is expanded in danger of joblessness then borrower unfit to pay. In harmony the banks charged high loan fee to more hazardous customers. Rinaldi and Sanchis-Arellano (2006) presumed that likelihood of default relies upon current pay, the joblessness rate and the loaning rate. The NPLs influenced by large scale monetary factors as well as influenced by the unmistakable highlights of the keeping money area and the approach decisions of every specific bank additionally impact on NPLs.

\section{Model specification and variable measures}

This model is connected under the presumption that the catch coefficients and slant are consistent after some time and crosswise over firms and all individual bank contrasts are clarified by mistake term and it is accepted that worldly changes and bank particular elements have less impact. There is linear 
association exist between non-performing loan and other explanatory variables. As all banks are supposed to have common internal features and they are not changing over time so that homogeneous data would obtain.

$$
Y_{i t}=\alpha+\beta X_{i t}+\mu_{i t}
$$

Where

$Y_{i t}$ a dependent variable.

$\alpha$ Stands for block term $\mu_{i t}$ is an error or residuals term.

\section{Pooled Least Square Model}

$$
N P L G A_{i t}=\phi_{0}+\sum_{i=1}^{N} \sum_{t=1}^{T} \phi_{i} Y_{i t}+\theta_{i t}
$$

Where NPLGA stands for non-performing loans to gross advances of banks $\mathrm{i}$ observed at time $\mathrm{t}$ : $\mathrm{t}=$ $2005 . . .2011$

$\phi_{0}$ Stands for block term.

$\beta$ is a $M \times 1$ vector of parameters to be estimated on $\phi_{i}$ is used for coefficients of illustrative variables. the independent variables. $X_{i t}$ is a $1 \times \mathrm{M}$ vector of observations on the independent variables?

$Y_{i t}$ is used for different explanatory variables explaining the changes in non-performing loan of Temporal dimension $\mathrm{t}$ varies from $\mathrm{t}=1 \ldots T$; and spatial dimension $i$ varies fromi $=1, N$.

bank $\mathrm{i}$ at time $\mathrm{t}$.

$\theta_{i t}$ Stands for residual or error term

$\mathrm{M}$ is used for the number of slope parameters to be estimated.

\section{Detailed Specification}

$$
\begin{aligned}
& N P L G A_{i t}=\phi_{0}+\phi_{1} U N_{i t}+\phi_{2} G D P_{i t}+\phi_{3} R L R_{i t}+\phi_{4} S R_{i t}+\phi_{5} M P_{i t}+ \\
& \phi_{6} S_{Z I} E_{i t}+\phi_{7} L O A N G_{i t}+\phi_{8} R O A_{i t}+\phi_{9} R O E_{i t}+\phi_{10} G A D+\phi_{11} I N E+\phi_{i t}
\end{aligned}
$$

\section{Assumptions of Methodology}

$>$ It is accepted that there is unidirectional circumstances and end results connection amongst needy and free factors.

$>$ In conventional pooled minimum square, it is expected that individual cross area's belongings and day and age particular impacts are same crosswise over areas and after some time period

$>$ There is direct affiliation exist between the free factor and other logical factors incorporated into an exploration.

$>$ In settled impact relapse investigation, because of little time measurement i.e.6 years, day and age particular impacts are accepted same.

\subsection{Definition of Variables Used in Regression Models}

> NPLGA: No-performing loans to Gross advances.

ROE: Return on equity is used as proxy for $\mathrm{Bad}$ management

ROA: Return on assets is used as proxy for Bad management

SR: Solvency ratio is used as proxy for Moral Hazard

GAD: Gross advances to deposits is used as proxy for Moral Hazard

INEF: Inefficiency is used as proxy for $\mathrm{Bad}$ Management

$>$ CR: Credit Growth is used as proxy for Procyclical credit policy.

$>$ MP: Market power is used as proxy for size

$>$ Size: Size itself is used as proxy for size.

\section{Variables and their Formula for calculation:}

The following tables describe the expected sign of above mentioned variables and previous studies in which these variables were used. 
International Journal of Trend in Scientific Research and Development (IJTSRD) ISSN: 2456-6470

Table1.

\begin{tabular}{|c|c|c|c|}
\hline Variables & Measurement & Used in Previous Studies & $\begin{array}{c}\text { Expected } \\
\text { Sign(Hypothesis) }\end{array}$ \\
\hline \multicolumn{4}{|c|}{ Dependent Variable } \\
\hline NPLGA & $\begin{array}{l}\text { Non-performing loan to Gross } \\
\text { advances ratio }\end{array}$ & $\begin{array}{c}\text { Babouèek and Janèar (2005) } \\
\text { Czech, Jakubík (2007) Czech,) } \\
\text { USA, Kalirai and Scheicher (2002) } \\
\text { Australia }\end{array}$ & \\
\hline UN & $\begin{array}{c}\text { Unemployment rate }=\text { Employed } \\
\text { population / Total working population } \\
\text { in a year }\end{array}$ & $\begin{array}{c}\text { Lawrence (1995), Salas and } \\
\text { Saurina (2002), Gambera (2000) } \\
\text { USA, }\end{array}$ & $(+) /-$ \\
\hline RLR & $\begin{array}{l}\text { Real lending rate }=\text { Fixed by SBP in } \\
\text { monetary policy. Here we used } \\
\text { KIBOR( Karachi Interbank offering } \\
\text { rate ) }\end{array}$ & $\begin{array}{c}\text { Keeton and Morries, } \\
\text { 1987,Lawrence (1995), Rinaldi } \\
\text { and Sanchis-Arellano (2006), Salas } \\
\text { and Saurina (2002), Jimenez and } \\
\text { Saurina, Arpa, Giulini and Pauer } \\
\text { (2001) Austrai, Kalirai and } \\
\text { Scheicher (2002) Australia }\end{array}$ & $(+) /-$ \\
\hline GDP & $\begin{array}{l}\text { Gross Domestic Product }= \\
\text { Consumption }+ \text { Investment }+ \\
\text { Govt.Spending }+ \text { Net Exports }\end{array}$ & $\begin{array}{l}\text { Lawrence (1995), Salas and } \\
\text { Saurina (2002) Spain, Arpa, } \\
\text { Giulini and Pauer (2001) Austria. }\end{array}$ & $+/(-)$ \\
\hline SR & $\begin{array}{l}\text { Solvency ratio= Owned capital / } \\
\text { Total Assets }\end{array}$ & $\begin{array}{l}\text { Louzis, vouldis and Metaxas } \\
\text { (2010) Greek } \\
\text { onall J ournal }\end{array}$ & $\begin{array}{l}\text { Moral hazard } \\
+/(-)\end{array}$ \\
\hline ROA & $\begin{array}{c}\text { Return on Assets= Profits/Total } \\
\text { Assets }\end{array}$ & $\begin{array}{c}\text { Louzis, vouldis and Metaxas } \\
\text { (2010) Greek. Männasoo and } \\
\text { Mayes (2009) }\end{array}$ & $\begin{array}{l}\text { Bad management } \\
\text { II }+/(-)\end{array}$ \\
\hline INEF & $\begin{array}{c}\text { Inefficiency }=\text { Operating Expenses } / \\
\text { Operating Income }\end{array}$ & $\begin{array}{l}10 \text { Louzis, vouldis and Metaxas } \\
\text { (2010) Greek }\end{array}$ & $\begin{array}{l}\text { Bad Management } \\
(+) /-\end{array}$ \\
\hline $\mathrm{CG}$ & Credit Growth $=$ Loal & $\begin{array}{l}\text { Babouèek and Janèar (2005) } \\
\text { Czech, Louzis, vouldis and } \\
\text { Metaxas (2010) Greek }\end{array}$ & $\begin{array}{l}\text { Procyclical credit } \\
\text { policy" } \\
(+) /-\end{array}$ \\
\hline $\mathrm{ROE}$ & ReturnonEquity=Profits/Total Equity & $\begin{array}{c}\text { Louzis, vouldis and Metaxas } \\
\text { (2010) Greek, Männasoo and } \\
\text { Mayes (2009) }\end{array}$ & $\begin{array}{c}\text { Bad management } \\
+/(-)\end{array}$ \\
\hline MP & $\begin{array}{c}\text { Market power }=\text { Banks Loans } / \text { All } \\
\text { banks Loans }\end{array}$ & $\begin{array}{l}\text { Sales and Saurina (2002)Spain, } \\
\text { Louzis, vouldis and Metaxas } \\
\text { (2010) Greek, }\end{array}$ & $\begin{array}{l}\text { Size } \\
+/(-)\end{array}$ \\
\hline Size & $\begin{array}{c}\text { Size }=\text { Total Assets of Bank/ Total } \\
\text { Assets of all Bank }\end{array}$ & $\begin{array}{c}\text { Sales and Saurina (2002)Spain, } \\
\text { Louzis, vouldis and Metaxas } \\
\text { (2010) Greek, Dash and Kabra } \\
\text { (2010) India }\end{array}$ & $\begin{array}{l}\text { Size } \\
+/(-)\end{array}$ \\
\hline GAD & $\begin{array}{l}\text { Gross Advance to Deposits= Loans/ } \\
\text { Deposits }\end{array}$ & $\begin{array}{l}\text { Louzis, vouldis and Metaxas } \\
\text { (2010) Greek, Jakubík (2007) } \\
\text { Czech, Männasoo and Mayes } \\
\text { (2009), Dash and Kabra (2010) } \\
\text { India, Festi et al. (2011) }\end{array}$ & $\begin{array}{l}\text { Moral hazard } \\
\qquad(+) /-\end{array}$ \\
\hline
\end{tabular}




\section{Empirical results and discussion Descriptive statistics}

In the wake of depicting system of this examination in past part, information investigation comes about are clarified in this section. This examination involves

both engaging and observational investigation. Distinct examination incorporates mean, middle, least esteem, most extreme esteem and standard deviation of the information. These methods are utilized to gauge the level of relationship amongst factors and to quantify the prescient energy of autonomous factors. Unmistakable examination uncovered that the factors utilized as a part of this investigation carried on diversely as far as their mean esteem and standard deviation both crosswise over time and crosswise over firms. The point by point clarification of the outcomes is given beneath:

\subsection{Regression Analysis and Empirical Methods}

Pooled Least Square Regression Analysis for Non-performing loans and its Determinants

Table2.

\begin{tabular}{|c|c|c|c|c|}
\hline \multirow{4}{*}{ 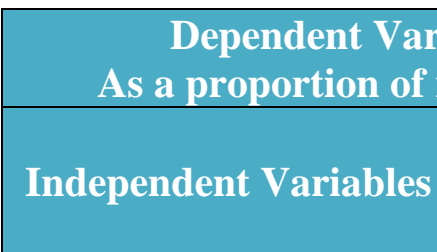 } & e: on- & ming & Gross ac & ces. \\
\hline & \multicolumn{4}{|c|}{ Estimation Methods } \\
\hline & \multicolumn{4}{|c|}{ Pooled Least Square } \\
\hline & Coefficient & t-Statistics & $p$-Value & S.D \\
\hline Intercept & -118.0356 & -2.506713 & $0.0130^{* *}$ & 47.08779 \\
\hline $\mathrm{UN}$ & 8.657464 & 1.597374 & 0.1116 & 4.797984 \\
\hline RLR & 4.424271 & 2.111509 & $0.0359^{*}$ & 1.975198 \\
\hline GDPR & 2.123413 & 1.296948 & 0.1960 & 1.314481 \\
\hline ROE & -0.442874 & -2.389879 & $0.0177 * *$ & 0.185312 \\
\hline SR & -0.252828 & -5.860935 & $0.00^{* * *}$ & 0.043138 \\
\hline $\mathrm{ROA}$ & -2.441591 & -5.719233 & $0.00 * * *$ & 0.426909 \\
\hline 00 & Reseal & hand & 0 & \\
\hline INEF & -13.09284 & -8.870513 & $0.00^{* * * *}$ & 1.475996 \\
\hline $\mathrm{CR}$ & -0.046349 & -0.548290 & 0.5840 & 0.084534 \\
\hline MP & -63.52363 & -1.762881 & $0.0793^{*}$ & 36.03398 \\
\hline Size & -1.040637 & -1.231124 & 0.2196 & 0.845274 \\
\hline GAD & 0.017326 & 3.587848 & $0.0004 * * *$ & 0.004829 \\
\hline Adjusted $\mathrm{R}^{2}$ & 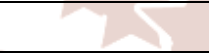 & 0.448829 & 3 & \\
\hline F- Statistics & & 13.91127 & & \\
\hline Durbin Watson Statistics & & 0.989048 & & \\
\hline
\end{tabular}

From the above table it is verified that $\mathrm{UN}$ is positively related with NPLs, but not too much significant on NPLs. It means that when the level of unemployment increases in the economy, it leads to increase in NPL but not significantly at 10\%.RLR having coefficient -4.424271 and it is significant at $5 \%$.It means when the interest rate in the economy is increase then borrower debt paying capacity become weak and it leads to increase in NPL.GDP having a coefficient 2.123413 and it is insignificant at $10 \%$ level of significance. The sign of coefficients implies that GDP is positively associated with NPLs. The
Return on Equity having coefficient -0.442874 and it is significant at $5 \%$. It means that when there is increase in return on equity then level of NPLs would fall. The coefficient of solvency ratio is -0.252828 and it is highly significant at $1 \%$.The sign of coefficient implies that there is negatively association presents between SR with NPLs. It means when solvency ratio increases by one unit then the level of NPLs would falls by 2.2 times. The coefficient of return on assets is -2.441591 and it is highly significant at $1 \%$. The coefficient sign represents that ROA is negatively associated with NPLs. The inefficiency having 
coefficient -13.09 and it also highly significant at $1 \%$ level of significance. The coefficient sign presents that INEF is negatively associated with NPLs. The coefficient of credit growth is -0.046 and it insignificant at $10 \%$ level of significance. The negative sign shows that $\mathrm{CR}$ is negatively associated with NPLs but too much significant. The market power having coefficient -63.52 and it is significant at $10 \%$ level of significance. It means that market power is negatively associated with NPLs. The coefficient of Size is -1.0406 and it is insignificant at $10 \%$. The sign of coefficient shows that there is negative association present between with NPLs and size. The GAD is also positively associated with NPLs and it is much significant at $1 \%$.

\section{Conclusion \& Recommendation:}

There are many empirical paper conducted to find out the determinants of firm bankruptcy or determinants of bankruptcy of banks. But determinant of bank specific have been less studied especially at bank level data. So this study is conducted to examine the impact of bank specific and macro-economic variables on non-performing loans in commercial banking of Pakistan. By understanding the behavior of different factors on problem loans, then bank can able to anticipate problem loans and avoid future bankruptcy. The study was aimed to find out the causes of continuously increasing non-performing loan whether bank specific variables like return on assets, return on equity, market power, size, solvency e.t.c. more influencing on NPLs or macro-economic variables like GDP growth rate, real lending rate, unemployment more influencing on NPLs. For this purpose panel data of 39 banks data for 6 year (2006--2011) has been used to measure the impact of input variables on NPLs through hypothesis testing and pooled ordinary least square model.

The study concluded that NPLs for private domestic banks is more than public banks which is 3.62 and 5.29 respectively. It means that public banks are more conservative in lending as private domestic bank, which focused on to increase their loan portfolio. In first two quarters of 2011 commercial banks showed high recovery and in third and fourth quarter banks became inefficient due to heavy flood and rain. In last five years saving and fixed deposits in commercial banking sector is continuously increasing as compare to current and call deposits, so banks enjoys high liquidity position. The credit risk of banking system also depends upon the management of economic cycle, how bank manager respond to changes in economic cycle. If there is steady growth then banks focused on increases bank loans, it is best economic policy for keeping a low level of problem. If GDP growth shows unexpected changes then bank must reinforce corrective action at the first sign of changes in the economic cycle. The degree of competition have non-linear impact on problem loans, when the competition increase, it will leads to decline in interest margin and manager incentive increases to take riskier creditors ultimately problem loans move up. If there is increase in market power allows the banks to charge high rent from their customer in future. The pooled OLS result showed that real lending rate is positive associated and highly significant at $5 \%$ level of significance of macro variables. Also bank specific variable like ROE, SR, ROA, inefficiency is negative associated with NPLs and highly significant at $1 \%$ level of significance.

\subsection{Policy Recommendations:}

The legal 'authorities should put more prominent accentuation on hazard administration frameworks and methodology took after by banks with a specific end goal to stay away from future monetary precariousness.

Bank directors should check whether the extra pay from advance development speaks to a satisfactory remuneration for the extra hazard taking. The saving money chiefs can screen credit development with a specific end goal to get early cautioning signals about the danger of individual banks

The NAB (National accountability bureau) must established mobile courts for early settlement of Problem loans cases and state bank of Pakistan must update the CIB (Credit information bureau) report on daily basis. So that the borrow may accurately evaluated.

When capital surpluses over regulatory minimum are low, banks may reduce lending, which, in turn, negatively affects the output levels?

The procedure for the collection of problem is complicated, harassment of defaulter by the recovery authorities is quite common, and this polluted their reputation of defaulter in the society, so bank should do a dialogue with default borrower with quiet patience. 
The bank supervisor must verify that risk premium charged on each loan operation is corresponding to the level of risk assumed, which is not occurred in most of the cases severe competition in the market.

The commercial banks must design a policy to diversify its credit portfolio in all industry rather to focus on one particular industry and dispersed it whole loan portfolio in it. Greater diversification would achieve by establishing more branches with in state, allowing interstate banking and encouraging secondary loan markets.

\section{Reference and Bibliography:}

1. Chandra, R. a. (2003). Non-Performing loans and terms of credit of public sector Banks in India:An emprical assessment . Reserve bank of india Occasional Papers, pp. vol, 24, No.3.

2. Huyghebaert, N. (2010). On the determinats and Dynamics of Trade credit use Empirical Evidence from Buiness Start Ups. Research report,, OR 0366

3. Prasad, R. E. (2010). Non performing Loans in the GCC banking system and their Macroeconomic effects. IMF working Paper, Middle East and Cental Asia department

4. Shahbaz Haneef, T. R. (2012, April ). Impact of Risk Management on Non-Performing Loans and Profitability of Banking Sector of Pakistan. International Journal of Business and Social Science Vol. 3 No. 7

5. M. farhan, A. S. (2012)." Economic Determinants of Non-Performing Loans: Perception of Pakistani Bankers " European Journal of Business and Management, vol 4 No 19

6. khalid, U. (2006). The effects of privatization and liberalization on banking sector performance in Pakistan. SBP Research Bulletin, Vol 2, no2

7. Adhikary, B. K. (1998).Non Performing loans and banking sector of bangladesh, Realities and challenges. Instituate of Bank and management , Dhaka

8. Ahmed, U., Farooq, S. Jalil, H. H. (2009). Efficiency Dynamics and Financial reforms: Case Study of Pakistani Banks. International Research Journal of Finance and Economics, 172-182

9. Kalian, H. and M. Scheicher, 2002. Macroeconomic Stress Testing: Preliminary
Evidence for Austria, Austrian National Bank Financial Stability Report, May, No. 3.

10. Gerlach, S., W. Peng and C. Shu, 2005. Macroeconomic conditions and banking performance in Hong Kong SAR: A panel data study. BIS Papers No. 22.

11. Shu, C., 2002. The Impact of Macroeconomic Environment on the Asset Quality of Hong Kong's

12. Banking Sector. Hong Kong Monetary Authority Research Memorandums.

13. Zeman, J. and P. Jurèa, 2008. Macro stress testing of the Slovak banking sector. Slovak National Bank,Bratislava Working Paper, No. 1/2008.

14. Jakubík, P., 2007. Macroeconomic environment and credit risk. Czech Journal of Economics and Finance, 10(1): 133-166

15. Babihuga, R., 2007. Macroeconomic and financial soundness indicators: An empirical investigation.IMF Working Paper, No. 07/115: Washington.

16. Podpiera, R., 2006. Does compliance with Basel Core Principles bring any measurable benefits? IMF Staff Paper No, 53(2): 306-325, Washington `

17. Festic, Mejra., Kavkler, Alenka. and Repina Sebastijan, 2011. The macroeconomic sources of Systemic risk in the banking sectors of five new EU member states. Journal of Banking and Finance, 35: 310-322

18. Dash, Manoj Kumar and Kabra Gaurav, 2010. The Determinants of Non-Performing Assets in Indian Commercial Bank: An Econometric Study. Middle Eastern Finance and Economics, 7: 94-106

19. Männasoo, K. and D. G. Mayes, 2009. Explaining bank distress in Eastern European transition economies. Journal of Banking and Finance, 33: 244-253.

20. Gambera, M., 2000. Simple Forecasts of Bank Loan Quality in the Business Cycle. Emerging Issues Series, Federal Reserve Bank of Chicago.

21. Salas, V. and J. Saurina, 2002. Credit Risk in Two Institutional Regimes: Spanish Commercial and Savings Banks. Journal of Financial Services Research, 22(3): 203-224.

22. Burki, A. A. and G. S. K. Niazi (2006). Impact of Financial Reforms on Efficiency of State-owned, Private, and Foreign Banks in Pakistan. CMER 
Working Paper No. 06-49. Lahore: Lahore University of Management Sciences

23. Ahmed, U., Farooq, S. Jalil, H. H. (2009). Efficiency Dynamics and Financial reforms: Case Study of Pakistani Banks. International Research Journal of Finance and Economics, 172-182.

\section{Annexure}

Nonperforming advances to add up to advances (NPL): Measures the benefit quality in the credit portfolio. It is ascertained by taking the estimation of NPLs as the numerator and the aggregate estimation of the credit portfolio (counting NPLs, and before the conclusion of particular advance misfortune arrangements) as the denominator.

Dependent Variable: NPLGA

Method: Panel Least Squares

Date: 07/15/13 Time: 13:13

Sample: 20062011

Periods included: 6

Cross-sections included: 39

Total panel (unbalanced) observations: 227

\begin{tabular}{|c|c|c|c|}
\hline Variable & Coefficient Std. Error & & Prob. \\
\hline $\begin{array}{l}\text { C } \\
\text { UN } \\
\text { GDPR } \\
\text { RLR }\end{array}$ & \begin{tabular}{l|l|l|}
-99.74678 & 55.41806 \\
8.791252 & 5.413008 \\
2.284530 & 1.630748 \\
4.615932 & 2.082217
\end{tabular} & $\begin{array}{l}-1 . \\
1.6 \\
1.4 \\
2.2\end{array}$ & $\begin{array}{l}0.0732 \\
0.1058 \\
0.1626 \\
0.0276\end{array}$ \\
\hline $\begin{array}{l}\text { R-squared } \\
\text { Adjusted R-squarec } \\
\text { S.E. of regression } \\
\text { Sum squared resid } \\
\text { Log likelihood } \\
\text { F-statistic } \\
\text { Prob(F-statistic) }\end{array}$ & $\begin{array}{cl}0.031296 & \text { Mean dependent var } \\
0.018264 & \text { S.D. dependent var } \\
19.21001 & \text { Akaike info criterion } \\
82292.45 & \text { Schwarz criterion } \\
-990.9642 & \text { Hannan-Quinn criter. } \\
2.401467 & \text { Durbin-Watson stat } \\
0.068586 & \end{array}$ & & $\begin{array}{l}19.38787 \\
8.766204 \\
8.826556 \\
8.790557 \\
0.527465\end{array}$ \\
\hline
\end{tabular}

Profit for resources (ROA): Measures store takers' effectiveness in utilizing their advantages. It is ascertained by isolating net pay (before charges) by the normal estimation of aggregate resources over a similar period.

Profit for value (ROE): Measures store takers' effectiveness in utilizing their capital. It is ascertained by partitioning net salary (net wage less gross costs) by the normal estimation of (capital and stores) over a similar period.

Dependent Variable: NPLGA

Method: Panel Least Squares

Date: 07/15/13 Time: 13:30

Sample: 20062011

Periods included: 6

Cross-sections included: 39

Total panel (unbalanced) observations: 227

\begin{tabular}{lllll}
\hline \hline Variable & Coefficient Std. Error & t-Statistic & Prob. \\
\hline \hline C & -88.79858 & 57.50546 & -1.544177 & 0.1240 \\
UN & 8.034761 & 5.518826 & 1.455882 & 0.1468 \\
GDPR & 2.215571 & 1.635276 & 1.354861 & 0.1768
\end{tabular}


International Journal of Trend in Scientific Research and Development (IJTSRD) ISSN: 2456-6470

\begin{tabular}{lllll} 
RLR & 3.805465 & 2.366558 & 1.608017 & 0.1093 \\
IFR & 0.248732 & 0.343902 & 0.723265 & 0.4703 \\
\hline \hline R-squared & 0.033573 & Mean dependent var & 14.64145 \\
Adjusted R-squared & 0.016160 & S.D. dependent var & 19.38787 \\
S.E. of regression & 19.23058 & Akaike info criterion & 8.772661 \\
Sum squared resid & 82099.00 & Schwarz criterion & 8.848100 \\
Log likelihood & -990.6970 & Hannan-Quinn criter. & 8.803102 \\
F-statistic & 1.928026 & Durbin-Watson stat & 0.520440 \\
Prob(F-statistic) & 0.106738 & & \\
\hline \hline
\end{tabular}

Dependent Variable: NPLGA

Method: Panel Least Squares

Date: 07/15/13 Time: 13:37

Sample: 20062011

Periods included: 6

Cross-sections included: 39

Total panel (unbalanced) observations: 225

\begin{tabular}{lllll}
\hline \hline Variable & \multicolumn{2}{c}{ Coefficient Std. Error } & t-Statistic & Prob. \\
\hline \hline C & -94.40298 & 55.68510 & -1.695300 & 0.0914 \\
UN & 8.657464 & 5.419809 & 1.597374 & 0.1116 \\
GDPR & 2.123413 & 1.637239 & 1.296948 & 0.1960 \\
RLR & 4.424271 & 2.095312 & 2.111509 & 0.0359 \\
MP & -63.52363 & 36.03398 & -1.762881 & 0.0793 \\
\hline \hline R-squared & 0.043998 & Mean dependent var & 14.60907 \\
Adjusted R-squared & 0.026617 & S.D. dependent var & 19.42373 \\
S.E. of regression & 19.16349 & Akaike info criterion & 8.765862 \\
Sum squared resid & 80792.64 & Schwarz criterion & 8.841776 \\
Log likelihood & -981.1595 & Hannan-Quinn criter. & 8.796501 \\
F-statistic & 2.531282 & Durbin-Watson stat & 0.533190 \\
Prob(F-statistic) & 0.041386 & & \\
\hline \hline
\end{tabular}

Dependent Variable: NPLGA

Method: Panel Least Squares

Date: 07/15/13 Time: 13:41

Sample: 20062011

Periods included: 6

Cross-sections included: 39

Total panel (unbalanced) observations: 227

\begin{tabular}{lcccl}
\hline \hline Variable & \multicolumn{2}{l}{ Coefficient Std. Error } & t-Statistic & Prob. \\
\hline \hline C & -88.79858 & 57.50546 & -1.544177 & 0.1240 \\
UN & 8.034761 & 5.518826 & 1.455882 & 0.1468 \\
GDPR & 2.215571 & 1.635276 & 1.354861 & 0.1768 \\
RLR & 3.805465 & 2.366558 & 1.608017 & 0.1093 \\
IFR & 0.248732 & 0.343902 & 0.723265 & 0.4703 \\
\hline \hline R-squared & 0.033573 & Mean dependent var & 14.64145
\end{tabular}




\begin{tabular}{llll} 
Adjusted R-squared & 0.016160 & S.D. dependent var & 19.38787 \\
S.E. of regression & 19.23058 & Akaike info criterion & 8.772661 \\
Sum squared resid & 82099.00 & Schwarz criterion & 8.848100 \\
Log likelihood & -990.6970 & Hannan-Quinn criter. & 8.803102 \\
F-statistic & 1.928026 & Durbin-Watson stat & 0.520440 \\
Prob(F-statistic) & 0.106738 & & \\
\hline
\end{tabular}

Dependent Variable: NPLGA

Method: Panel Least Squares

Date: 07/15/13 Time: 13:43

Sample: 20062011

Periods included: 6

Cross-sections included: 39

Total panel (unbalanced) observations: 227

\begin{tabular}{lllll}
\hline \hline Variable & Coefficient Std. Error & t-Statistic & Prob. \\
\hline \hline C & -105.5840 & 55.55678 & -1.900469 & 0.0587 \\
UN & 10.94017 & 5.681533 & 1.925567 & 0.0554 \\
GDPR & 2.177555 & 1.631181 & 1.334956 & 0.1833 \\
RLR & 4.179983 & 2.109744 & 1.981275 & 0.0488 \\
SIZE & -1.040637 & 0.845274 & -1.231124 & 0.2196 \\
\hline \hline R-squared & 0.037864 & Mean dependent var & 14.64145 \\
Adjusted R-squared & 0.020529 & S.D. dependent var & 19.38787 \\
S.E. of regression & 19.18784 & Akaike info criterion & 8.768210 \\
Sum squared resid & 81734.43 & Schwarz criterion & 8.843650 \\
Log likelihood & -990.1919 & Hannan-Quinn criter. & 8.798651 \\
F-statistic & 2.184182 & Durbin-Watson stat & 0.536985 \\
Prob(F-statistic) & 0.071693 & & & \\
\hline \hline
\end{tabular}

Dependent Variable: NPLGA

Method: Panel Least Squares

Date: 07/15/13 Time: 13:44

Sample: 20062011

Periods included: 6

Cross-sections included: 39

Total panel (unbalanced) observations: 225

\begin{tabular}{lllll}
\hline \hline Variable & \multicolumn{2}{l}{ Coefficient Std. Error } & t-Statistic & Prob. \\
\hline \hline C & -108.8566 & 52.40528 & -2.077207 & 0.0389 \\
UN & 9.436764 & 5.115221 & 1.844840 & 0.0664 \\
GDPR & 2.753656 & 1.543722 & 1.783777 & 0.0758 \\
RLR & 4.913007 & 1.973121 & 2.489968 & 0.0135 \\
ROA & -2.441591 & 0.426909 & -5.719233 & 0.0000 \\
\hline \hline R-squared & 0.155453 & Mean dependent var & 14.60267 \\
Adjusted R-squared & 0.140097 & S.D. dependent var & 19.45288 \\
S.E. of regression & 18.03884 & Akaike info criterion & 8.644903 \\
Sum squared resid & 71587.95 & Schwarz criterion & 8.720817 \\
Log likelihood & -967.5516 & Hannan-Quinn criter. & 8.675542
\end{tabular}


Dependent Variable: NPLGA

Method: Panel Least Squares

Date: 07/15/13 Time: 13:44

Sample: 20062011

Periods included: 6

Cross-sections included: 39

Total panel (unbalanced) observations: 227

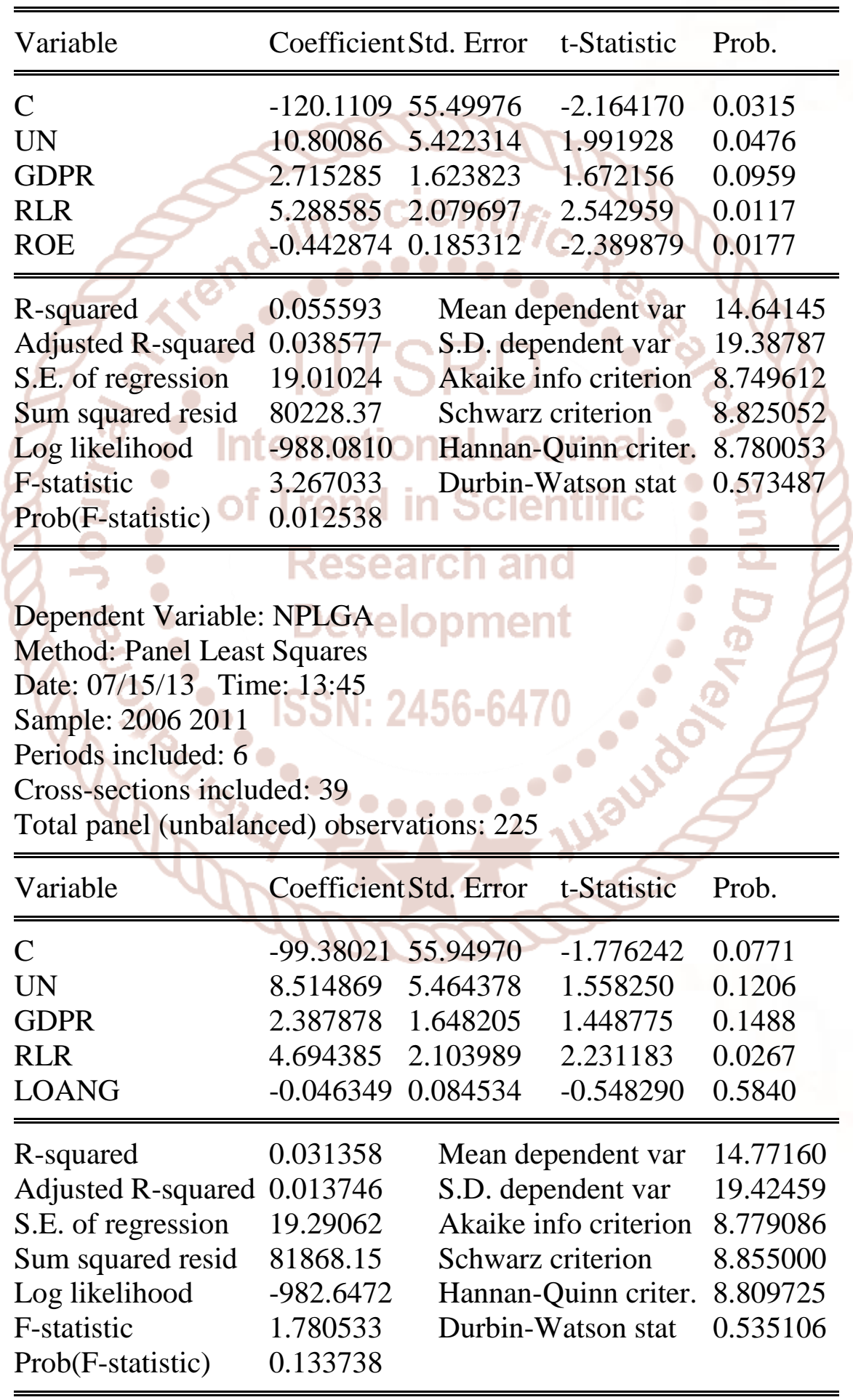


Dependent Variable: NPLGA

Method: Panel Least Squares

Date: 07/15/13 Time: 13:45

Sample: 20062011

Periods included: 6

Cross-sections included: 39

Total panel (unbalanced) observations: 224

\begin{tabular}{lllll}
\hline \hline Variable & Coefficient Std. Error & t-Statistic & Prob. \\
\hline \hline C & -107.8042 & 54.39591 & -1.981845 & 0.0487 \\
UN & 9.368600 & 5.353248 & 1.750078 & 0.0815 \\
GDPR & 2.311210 & 1.596747 & 1.447449 & 0.1492 \\
RLR & 4.818112 & 2.043753 & 2.357483 & 0.0193 \\
GAD & 0.017326 & 0.004829 & 3.587848 & 0.0004 \\
\hline \hline R-squared & 0.084723 & Mean dependent var & 14.73094 \\
Adjusted R-squared & 0.068006 & S.D. dependent var & 19.47674 \\
S.E. of regression & 18.80281 & Akaike info criterion & 8.727958 \\
Sum squared resid & 77426.51 & Schwarz criterion & 8.804111 \\
Log likelihood & -972.5313 & Hannan-Quinn criter. & 8.758697 \\
F-statistic & 5.067985 & Durbin-Watson stat & 0.561177 \\
Prob(F-statistic) & 0.000634 & & \\
\hline \hline
\end{tabular}

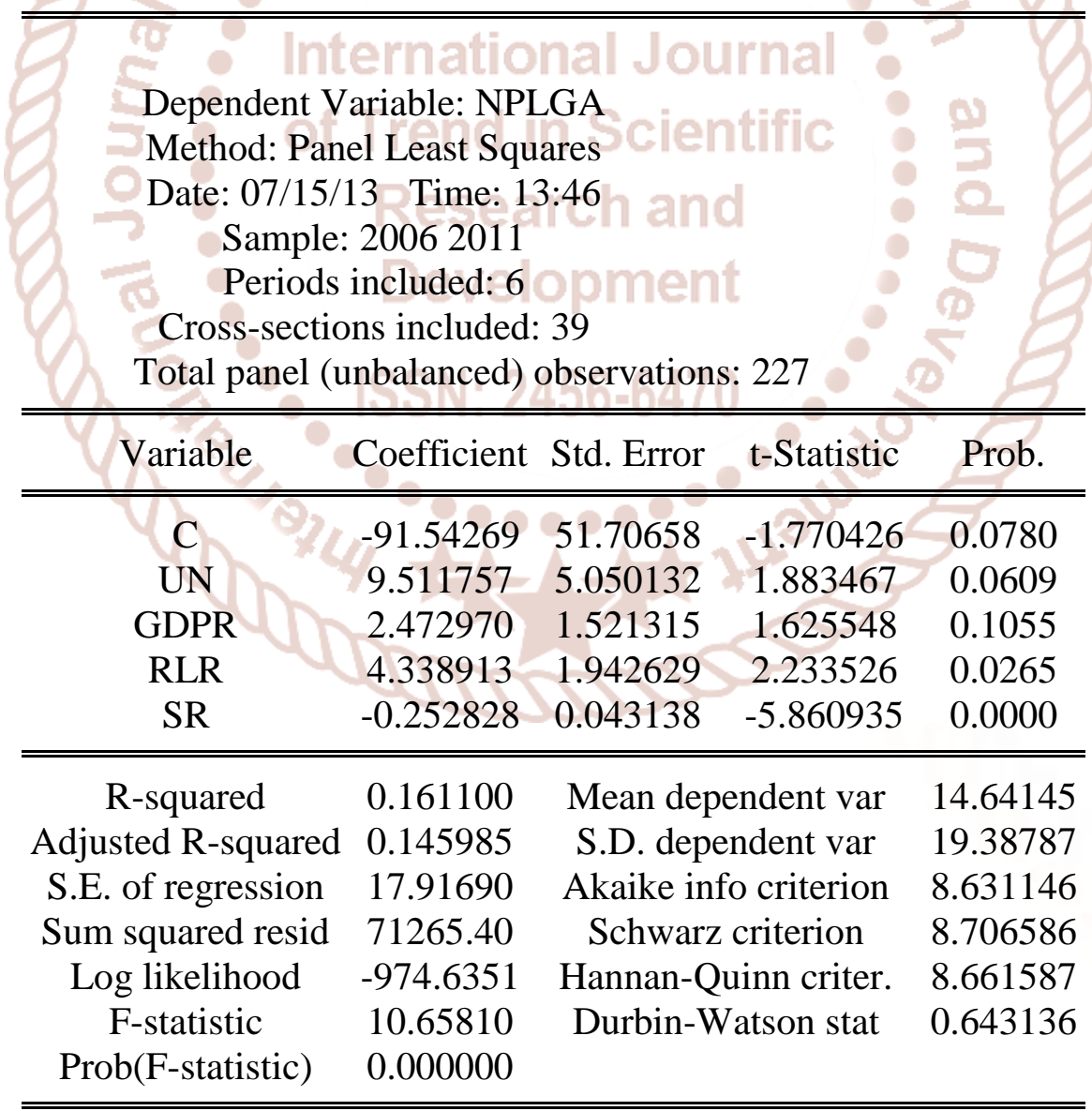

Dependent Variable: NPLGA

Method: Panel Least Squares

Date: 07/15/13 Time: 13:49

Sample: 20062011 
Periods included: 6

Cross-sections included: 39

Total panel (unbalanced) observations: 227

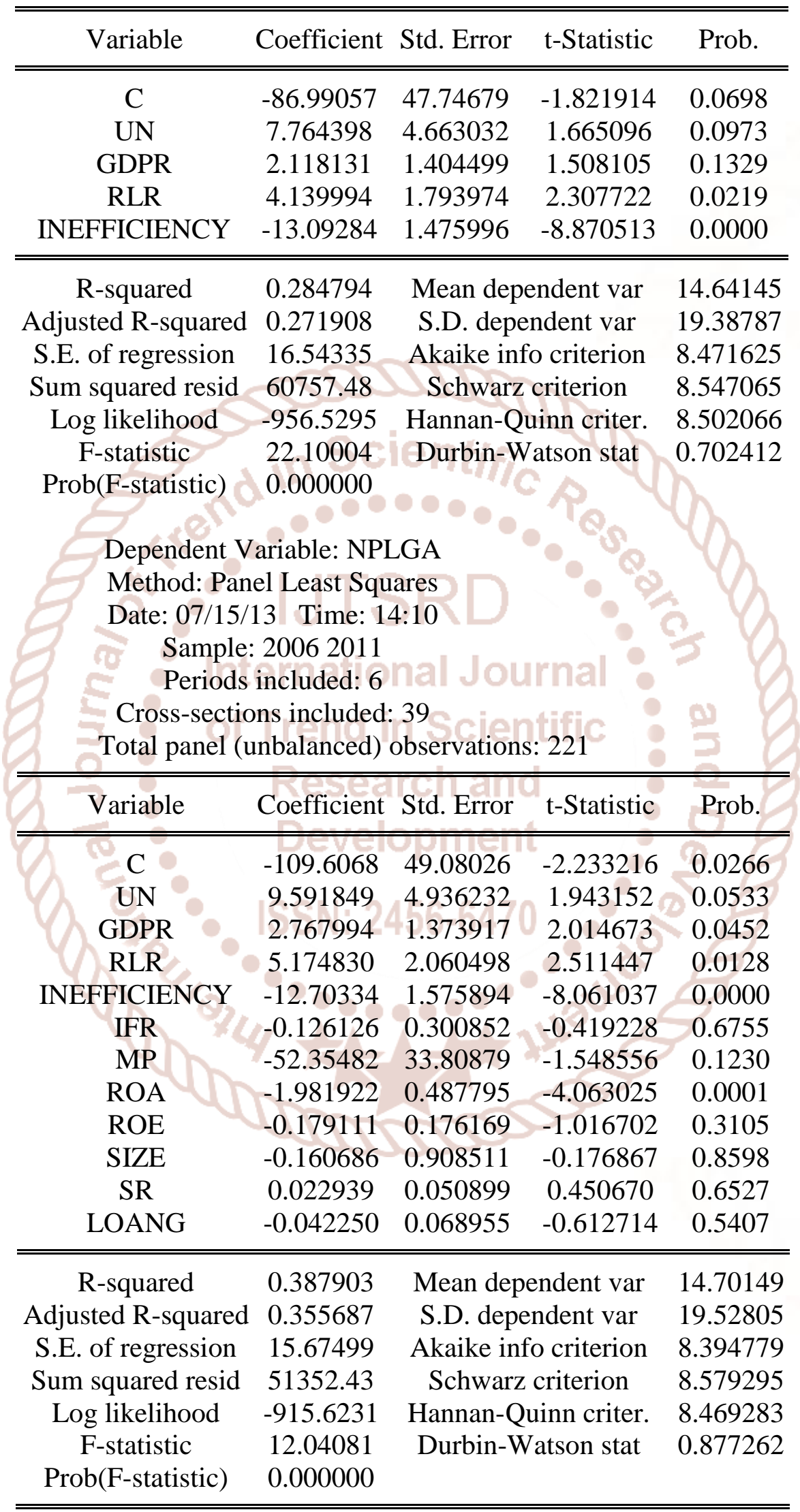


Dependent Variable: NPLGA

Method: Panel Least Squares

Date: 07/15/13 Time: 14:12

Sample: 20062011

Periods included: 6

Cross-sections included: 39

Total panel (unbalanced) observations: 218

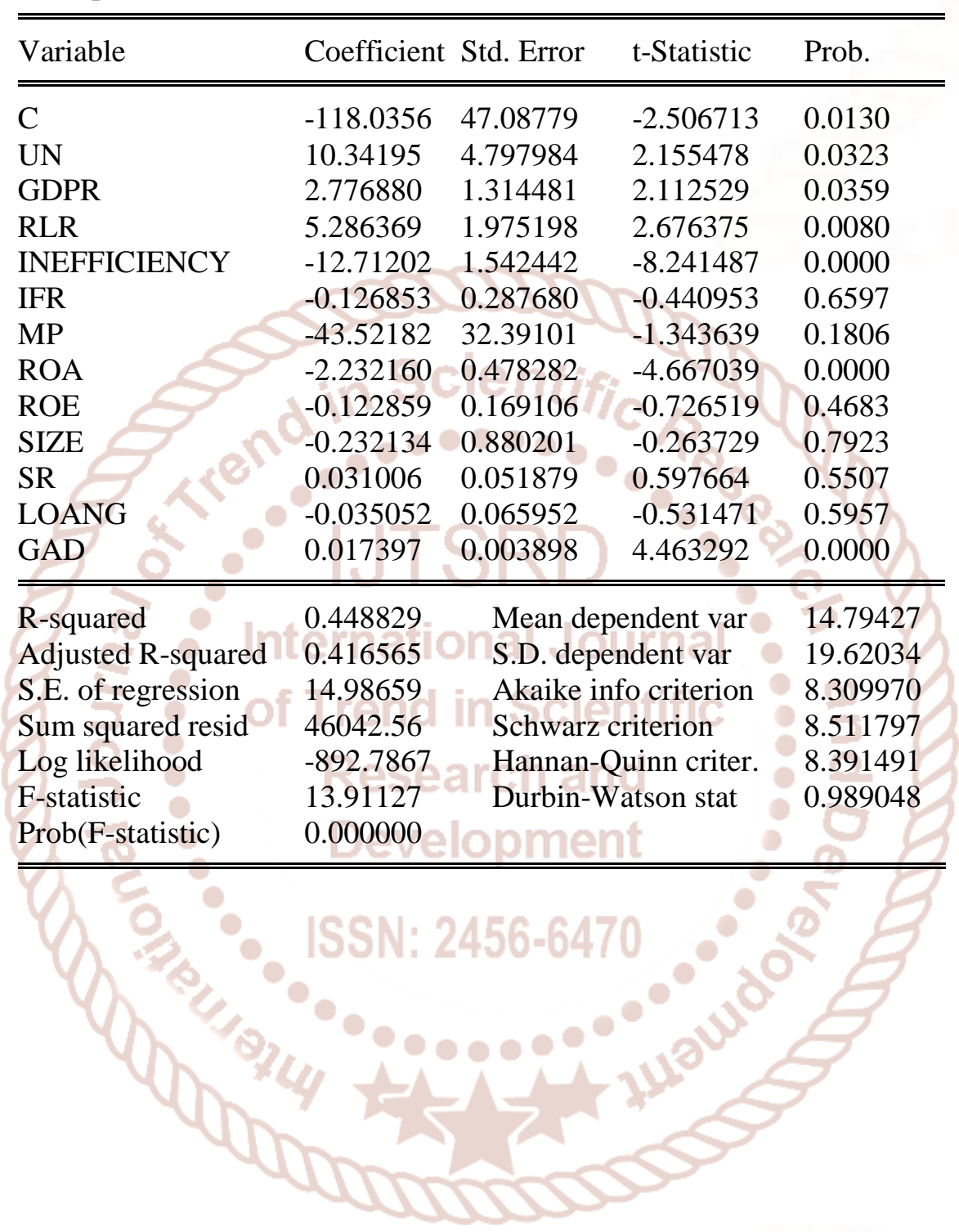

